\title{
Cretaceous Algal Palynomorphs from Northeast Sinai, Egypt: Systematics and Paleoenvironmental Implications
}

\author{
Zainab M. EI Noamani" and Amal I. Saleh \\ Botany Department, Faculty of Science, Ain Shams University, Cairo, 11566, Egypt.
}

$\mathbf{T}$

HE microalgal palynomorphs considered one of the main categories of non-pollen palynomorphs recognized in palynological slides which characterized by their potential paleoecological and stratigraphical values especially in the pre-Quaternary deposits. For this importance, four subsurface cutting samples recovered from two Cretaceous (Aptian/Albian and Turonian) geological units in Bougaz-1 well, northeast Sinai have been palynologically analyzed in order to study their algal content. Seven species of algae related to four genera from two divisions have been described and illustrated: Pediastrum boryanum, $P$. duplex, $P$. kawraiskyi, P. simplex, Scenedesmus acuminatus, and Chomotriletes minor (Chlorophyta); and Pterospermella sp. (Prasinophyta). Of these, two species (Pediastrum kawraiskyi and Scenedesmus acuminatus) are recorded for the first time from the Cretaceous of Egypt. Notes on the stratigraphic range and the geographical distribution of the most important recorded genera are given. The cell wall nature and its role in resistance to degradation are also discussed. The ecology of extant taxa has been used to determine the paleoenvironment and paleoecology prevailed in the studied area during the Cretaceous period.

Keywords: Chlorophycean algae, Cretaceous, Egypt, Non-pollen palynomorphs, Paleoecology, Palynology.

\section{Introduction}

In paleopalynology, in addition to spores and pollen of vascular plants, there are different non-pollen palynomorphs (NPPs) which contribute the total organic matter in sediments such as dinoflagellate cysts, chitinous fungal remains, certain types of microscopic algae, acritarchs, microforaminifera linner test linings, scolecodonts, chitinozoans and arthropod remains can be recognized in palynological slides. These NPPs consisted of organic-walled microfossils which composed of sporopollenin-like or chitin/ pseudochitin polymers which are often making them more resistant to corrosion and oxidation than pollen and spores, and they are not destroyed during chemical treatment of the sample with strong acids (HCL-HF acid treatments) (Traverse, 2007).

Of the main categories of NPPs is microalgal palynomorphs which represented by a group of acid resistant organic walled microfossils attributed to various types of fresh and marine water algae including cyanobacteria (blue green algae), unicellular and colonial chlorophytes (such as Botryococcus, Pediastrum and Scenedesmus coenobia), filamentous zygnemataceans (a group of green algae produce resting spores with a sporopollenin-like cell wall) and prasinophyte phycomata (the fossilized cyst that represent the non-motile stage of prasinophyceae). Prasinophyte represents the oldest group of the green algae; their extant forms occur in fresh to hypersaline water, but fossil forms (non-motile stage) are exclusively marine (Mendonça Filho et al., 2012).

Most cyanobacteria and algal taxa have a much longer geological history than miospore producing groups (bryophytes, pteridophytes, gymnosperms and angiosperms). Like most aquatic organisms, algae has an important ecological advantage in that its ability to react quickly to environmental changes and respond to different parameters (e.g., length of openwater season, nutrient availability and water temperature) than the terrestrial vegetation (Sarmaja-Korjonen et al., 2006). In addition, the presence of some colonial algae in sediments of different ages has been largely recognized as one of the most reliable paleoecological markers of fresh water environments, in particular, of

"Corresponding author email: zainabelnoamani@yahoo.com 
standing water bodies such as ponds and lakes (Tell \& Zamaloa, 2004). Therefore, some of them are interesting for palynologists especially in the analysis of pre-Quaternary deposits (Gawlik \& Millington, 1969).

Despite their potential paleoecological and stratigraphical values, the algal elements are rarely illustrated and/or identified below the genus level in the palynological studies. Nevertheless, the identification of the fossil/subfossil species provide us with important paleoenvironmental inferences by comparison with the known ecological requirements of the living counterparts (Tell \& Zamaloa, 2004).

The purpose of this paper is to identify to the species level and describe the algal assemblage present in the Cretaceous samples recovered from Bougaz-1 well, northeast Sinai, in addition to a compilation of the known stratigraphic range and paleogeographic extent of the most common chlorococcale colonial genera present in the palynological slides based on their previous records compiled from Palynodata Inc. \& White (2008). Finally, interpretations about the paleoecology of the recorded genera are discussed.

\section{Materials and Methods}

The algal assemblage which is the subject of this study is recorded from four subsurface cutting samples coming from two Cretaceous (Aptian/ Albian to Turonian) geological units in Bougaz-1 (B-1) well. Samples no. $1 \& 2$ was taken from the Turonian unit at depths 3093 m \& 3078 m, while samples no. $3 \& 4$ was taken from Aptian/Albian unit at depths $3117 \mathrm{~m} \& 3105 \mathrm{~m}$, respectively. This well was drilled to a total depth of about 3540.9 $\mathrm{m}$ by Continental Delta Oil Company (Conoco) during 1982. It is located at latitude $31^{\circ} 09^{\prime} 24.6^{\prime \prime}$ $\mathrm{N}$ and longitude $32^{\circ} 40^{\prime} 47.55^{\prime \prime} \mathrm{E}$, near Bardawil Lake, northwest Sinai (Fig. 1)

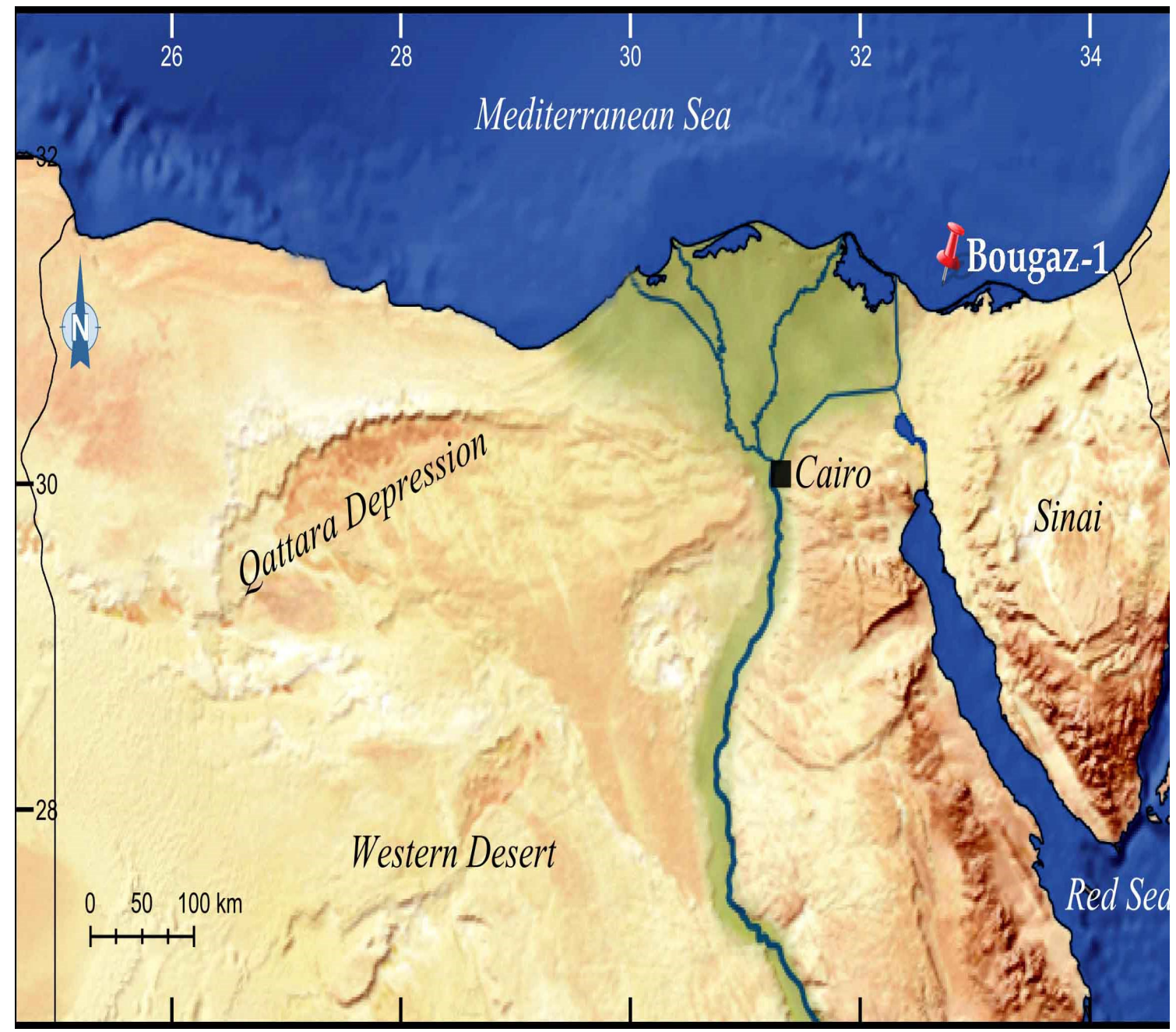

Fig. 1. Location map of Bougaz-1 (B-1) well (modified after Ibrahim et al., 2017). 
The recovered samples were processed using the standard palynological preparation technique for extraction and concentration of palynomorphs, including $\mathrm{HCl}$ and $\mathrm{HF}$ treatments and subsequent sieving with a nylon filtering screen $(15 \mu \mathrm{m}$ mesh); no oxidation was applied (cf. Traverse, 2007 and Ibrahim et al., 2017). Two slides per sample were prepared using DPX as mounting medium. The smear slides were examined using a DEL binocular biological compound microscope equipped with a Canon PowerShot G12 digital camera for photomicrography. Coordinates for all illustrated specimens are cited as England Finder references. Identification of the recorded species was carried out according to Prescott (1962), Pocock (1970), Eisenack (1972) and Hortobagyi (1973).

The slides and the remaining residues are deposited in the Paleobotany and Palynology Lab, Botany Department, Faculty of Science, Ain Shams University, Egypt.

\section{Results}

In the present study seven algal species belonging to two different divisions (Chlorophyta and Prasinophyta) were identified. Out of which four species were related to genus Pediastrum and one species each for Scenedesmus, Chomotriletes and Pterospermella. The identity of the latter species remains unknown.

Within the genus Pediastrum, P. boryanum was the dominant species and recorded in the four samples, P. simplex and P. duplex were frequent in the four samples and $P$. kawraiskyi was rare and recorded only in one sample (sample no. 1). Scenedesmus acuminatus was frequent and recorded in two samples no. $1 \&$ 3; while Chomotriletes minor was recorded only in Aptian/Albian samples (samples no. 3 \& 4). Pterospermella sp. was represented by very rare specimens from Aptian/Albian interval (samples no. $3 \& 4)$.

\section{Systematic description:}

Division $_{1}$ : Chlorophyta Pascher

Class: Chlorophyceae Kützing

Order: Chlorococcales Marchand

Family 1 : Hydrodictyaceae (Gray) Dumortier

Genus: Pediastrum Meyen

Family $_{2}$ : Scenedesmaceae Oltmanns

Genus: Scenedesmus Meyen

Order $:$ Zygnematales Borge

Family Zygnemataceae (Meneghini) Kützing Genus: Chomotriletes Naumova
Division $_{2}$ : Prasinophyta Round

Class: Prasinophyceae Christensen ex Moestrup

\& Throndsen

Order: Petrospermatales Schiller

Family: Petrospermellaceae Eisenack

Genus: Pterospermella Eisenack

\section{Genus: Pediastrum Meyen}

The distinctive morphological feature of the genus is the arrangement of the inner and outer cells into flat circular coenobia. The several species within the genus are distinguished by the number of cells in coenobia, shape of internal and external cells, wall ornamentation, presence or absence of spaces between the inner cells and the number, shape and orientation of the horns of the outermost ring of cells (Tell \& Zamaloa, 2004).

In the present study, Pediastrum is represented by four species; $P$. boryanum, $P$. duplex, P. kawraiskyi and P. simplex.

P. boryanum (Turpin) Meneghini (Plate 1, Fig. 1-3)

Description: Colony circular to ovoid, of $8,16,32$ or more cells, without perforations between the cells. Inner cells 4-6 sides, with undulated or straight sides. Outer half of marginal cells produced into two long horn-like processes. Colony $50-61 \mu \mathrm{m}$ in diameter. Cells $9-13 \mu \mathrm{m}$ in diameter, 10-17 $\mu \mathrm{m}$ long with the processes.

Remarks: The absence of holes in the coenobia and the external cells with two horns in the same plane clearly distinguish the species. This is the most widely distributed and variable species among Pediastrum.

\section{P. duplex Meyen (Plate 1, Fig. 4 and 5)}

Description: Colony 8-128 celled, the walls smooth or granulated (punctate), with clear spaces between the inner cells; inner and peripheral cells quadrate, the outer margin of the peripheral cells extended into 2 tapering, blunttipped processes and in some cases the processes ended with globules, distance between processes of one cell about one-half the distance between processes of adjacent cells; cells $5.5-10 \mu \mathrm{m}$ in diameter; $12-17 \mu \mathrm{m}$ long with the processes. 16-celled colony $51 \mu \mathrm{m}$ in diameter.

Remarks: The species is easy to distinguish from the other species because of the regularly displaced holes between cells in the coenobia and the distinct two horns of the marginal cells in the same plane. 


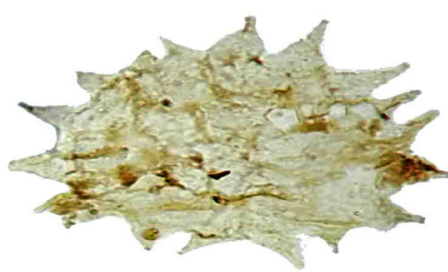

1

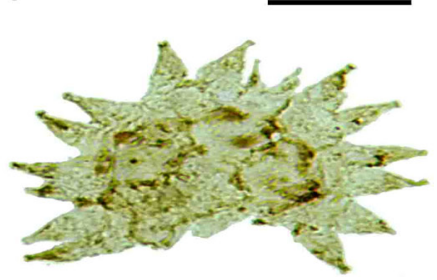

4

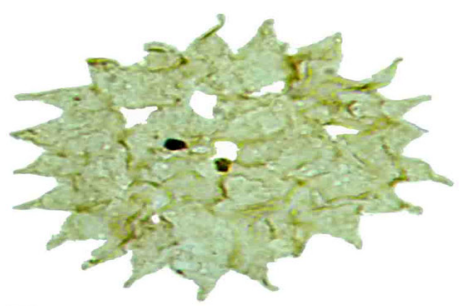

7

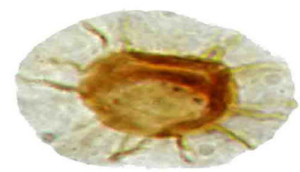

10

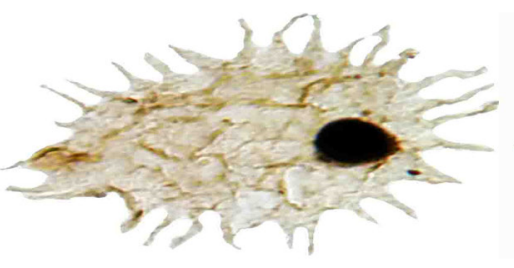

2

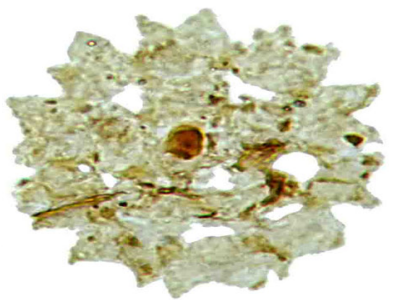

5

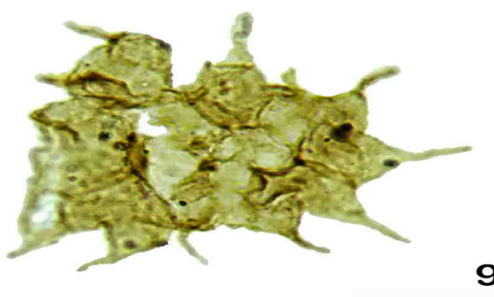

8

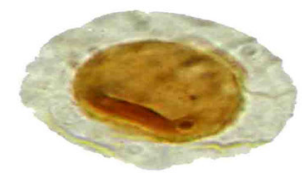

11

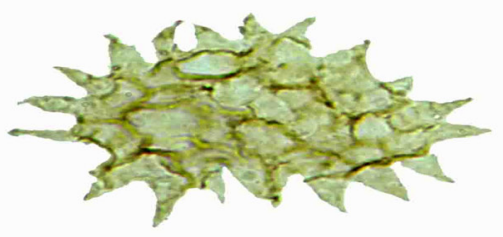

3

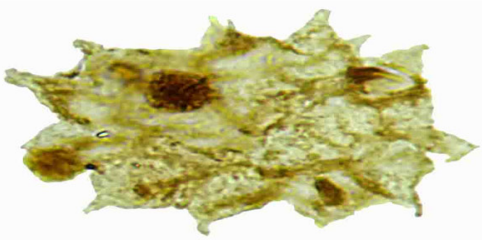

6

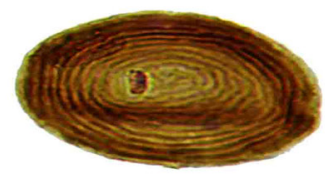

9

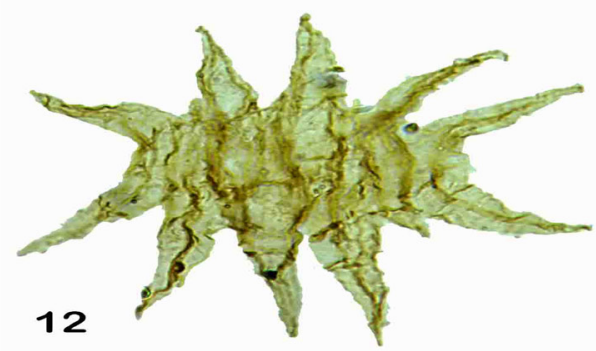

Plate 1

Specimens are denoted by the well name abbreviation (B-1), sample number/slide number, England finder slide location, and scale bar length.

Fig. 1-3. Pediastrum boryanum (Turpin) Meneghini.

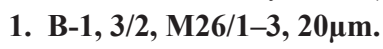

2. B-1, $4 / 1,038 / 1-2,18 \mu \mathrm{m}$.

3. B-1, 1/1, V23/3-4, 15um.

Fig. 4 and 5. Pediastrum duplex Meyen.

4. B-1, 2/1, V28/3, 18um.

5. B-1, 3/2, Y42/2, 16 $\mu \mathrm{m}$.

Fig. 6. Pediastrum kawraiskyi Schmidle; B-1, 1/1, L32/0, $15 \mu \mathrm{m}$.

Fig. 7 and 8..Pediastrum simplex Meyen.

7. B-1, 2/1, M27/2, $17 \mu \mathrm{m}$.

8. B-1, 2/1, Y36/4, 15 $\mu \mathrm{m}$.

Fig. 9. Chomotriletes minor (Kedves) Pocock; B-1, 3/4, N34/0, 18um.

Fig. 10 and 11. Pterospermella sp.

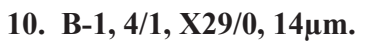

11. B-1, 3/1, J27/2-4, $13 \mu \mathrm{m}$.

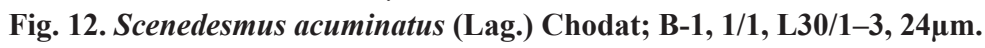




\section{P. kawraiskyi Schmidle (Plate 1, Fig. 6)}

Description: The colony consists of 16 cells. Peripheral cells napiform, the outer margin extended into 2 projections which are not in the same plane, one usually directly above the other. Colony $53 \mu \mathrm{m}$ in diameter. Cells $8-12 \mu \mathrm{m}$ in diameter, $10-13 \mu \mathrm{m}$ long with the processes.

Remarks: This species is characterized by the flat or frequently twisted coenobia, without holes, the lobes of the marginal cells oriented in different planes.

\section{P. simplex Meyen (Plate 1, Fig. 7 and 8)}

Description: Colonies circular, of 4, 8, 16 or more cells, outer half of the marginal cells with a single, long horn-like process. Cell wall smooth or granulate. Colony $45-50 \mu \mathrm{m}$ in diameter. Cells 6-12 $\mu \mathrm{m}$ in diameter, $10-18 \mu \mathrm{m}$ long with the process.

Remarks: The marginal cells of this species is extended to give only oneprocess. According to Komárek \& Jankovská (2001) perforations in the coenobia may or may not be present.

\section{Genus: Scenedesmus Meyen}

Species of Scenedesmus are mainly differentiated according to the arrangement of cells (in one or two rows) and the presence or absence of terminal spine-like processes.

In the present study Scenedesmus is represented by only one species, S. acuminatus.

S.acuminatus (Lag.) Chodat (Plate 1, Fig. 12)

Description: The colony consists of 4-8 elongated laterally united cells arranged in different planes. The two outer cells are strongly lunate. All cells have sharply pointed apices. Cells $8-19 \mu \mathrm{m}$ in diameter, 58-76 $\mu \mathrm{m}$ long.

\section{Genus: ChomotriletesNaumova}

C. minor (Kedves) Pocock (Plate 1, Fig. 9)

Description: Alete spore, outline subcircular, thin wall, ornamented with a series of subcircular ridges separated by furrows arranged in concentric circles parallel to the equatorial margin. Maximum diameter is $37 \mu \mathrm{m}$.

\section{Genus: Pterospermella Eisenack}

Pterospermella sp. (Plate 1, Fig. 10 and 11)

Description: This species is characterized by an ellipsoidal central body surrounded by an elliptical equatorial wing, which has a few fine radial folds. Its overall diameter including the wing is $25-27$ $\mu \mathrm{m}$, diameter of the central body is $13-14.5 \mu \mathrm{m}$, and width of the wing is $12-12.5 \mu \mathrm{m}$.

\section{Discussion and Conclusion}

Chlorophyceae are a widely diversified group of aquatic algae comprising more than 7800 modern species embodied in 520 genera. Their fossil record extends back to the Cambrian period, 540 million years ago (Girard, 2009).

Pediastrum, the most common genus of fossilizing chlorococcale algae, exhibits a long fossil record extends back to the Early Cretaceous, and at least as early as the late Barremian (Evitt, 1969). It is one of the most important fossilizing algal genera, besides Botryococcus, that are responsible for the formation of excellent petroleum source rocks in Cretaceous and Cenozoic basins (Mendonça Filho et al., 2012).

The cell wall of Pediastrum is composed of two layers, a thick cellulose inner layer, and a thin outer sporopollenin layer which carries surface sculpture of the cell. Sporopollenin is a unique group of resistant biopolymers derived by the oxidative polymerization of carotenoids and (or) carotenoid esters that are resistant to destruction during fossilization and chemical laboratory processing by alkali and strong acids such as hydrochloric acid $(\mathrm{HCl})$ and Hydrofloric acid (HF) normally used for preparing pollen samples, but are degraded only by oxidizing agents such as Nitric acid and Chromic acid (Brunner \& Honegger, 1985 and Brooks \& Shaw, 1972). In palynological preparations only the sporopollenin layer is retained without cell contents. From this layer we can recognize the shape, surface sculpture and arrangement of cells in coenobia (Komárek \& Jankovská, 2001).

According to data extracted from Palynodata Inc. \& White (2008), there are 35 species of Pediastrum recorded worldwide from different geological strata (Table 1). Some of them are long-ranged and survived to the present day (such as P. boryannum, $P$. duplex, $P$. kawraiskyi, and P. simplex) while others are not known till now from the recent microflora (such as $P$. difforme, which was described earlier from the Neogene of China, USA and Germany (Komárek \& Jankovská, 2001)). The geographical distribution of Pediastrum species is mainly determined by two factors: the temperature (in case of global distribution) and water quality (for regional distribution) (Tell, 2004). 
TABLE 1. Previous world-wide records of Pediastrum species compiled from Palynodata Inc. \& White (2008).

\begin{tabular}{|c|c|c|}
\hline \multirow{3}{*}{ Name of species } & $\begin{array}{c}\text { Age range } \\
\end{array}$ & \multirow{3}{*}{ Geolocation } \\
\hline & $\begin{array}{ll}\text { Mesozoic } & \text { Cenozoic } \\
\end{array}$ & \\
\hline & $\overline{\text { Cretaceous Paleogene Neogene Quaternary }}$ & \\
\hline \multicolumn{2}{|c|}{ Pediastrum angulatus $=$} & India, Pacific Ocean \\
\hline P. araneosam & \multicolumn{2}{|r|}{ China } \\
\hline P. bellulum & \multicolumn{2}{|r|}{ China } \\
\hline P. bifidites & \multicolumn{2}{|r|}{ England, India, Indonesia, N. America } \\
\hline P. bifurcatum & \multicolumn{2}{|r|}{ China } \\
\hline P. bimammilosum & \multicolumn{2}{|r|}{ China } \\
\hline P. biradiatum & \multicolumn{2}{|r|}{ China } \\
\hline P. boryanum & \multicolumn{2}{|r|}{$\begin{array}{l}\text { Africa, Australia, China, Egypt, India, Korea, } \\
\text { N. America, Thailand, S. America, }\end{array}$} \\
\hline P. clathratum & \multicolumn{2}{|r|}{ China } \\
\hline P. coenobia & \multicolumn{2}{|r|}{ Africa } \\
\hline P. compactum & \multicolumn{2}{|r|}{ India } \\
\hline P. delicatites & \multicolumn{2}{|r|}{ India, N. America } \\
\hline P. delicatus & \multicolumn{2}{|r|}{ Indonesia } \\
\hline$P$. difforme & \multicolumn{2}{|r|}{ China, Germany, USA } \\
\hline P. diffuses & \multicolumn{2}{|r|}{ India } \\
\hline & \multicolumn{2}{|r|}{ Africa, China, Egypt, N. America, S. America, } \\
\hline P. duplex & \multicolumn{2}{|r|}{ Thailand, USSR } \\
\hline P. elongatum & \multicolumn{2}{|r|}{ China } \\
\hline P. fimorphum & \multicolumn{2}{|r|}{ China } \\
\hline P. indicum & \multicolumn{2}{|r|}{ China, Germany } \\
\hline P. integrum & \multicolumn{2}{|r|}{ Africa, China, Indonesia, Korea, N. America } \\
\hline P. kajaites & \multicolumn{2}{|r|}{ Africa, China, Germany, USSR } \\
\hline P. kawraiskyi & \multicolumn{2}{|r|}{ India } \\
\hline P. magnus & \multicolumn{2}{|r|}{ India, China } \\
\hline P. multidentatum & & N. America \\
\hline P. muticum & & Malaysia \\
\hline P. nanningense & & Indonesia, N. America \\
\hline P. ovatum & & Brazil \\
\hline P.paleogeneites & & Africa, Belgium, India, N. America, S. America \\
\hline P. pallidus & & China, India \\
\hline P. parakawraiskyi & & India \\
\hline P. quadriangalatum & & China \\
\hline$P$. radiates & & China, Romania \\
\hline P. rostriforme & & France, USSR \\
\hline P. shangsicum & & Hungary \\
\hline P. simplex & & $\begin{array}{l}\text { Africa, China, Egypt, Europe, Japan, Thailand, } \\
\text { S. America }\end{array}$ \\
\hline
\end{tabular}


Extant representatives of Pediastrum are exclusively found in fresh water, especially in meso-eutrophic and eutrophic waters with high nutrient contents mainly nitrogen and phosphorus (Prasertsin et al., 2014). There is an inverse relationship between the growth rate of Pediastrum and Botryococcus, where they occur together the much greater growth rate of Pediastrum, the much growth suppression of Botryocoocus, because they compete in the same environment (Mendonça Filho et al., 2012). But with respect to salinity, Pediastrum appears to be less tolerant to elevated salinities than Botryococcus (Tyson, 1993). On the species level, $P$. boryanum and $P$. kawraiskyi can tolerate salinities up to $8 \%$, but $P$. duplex and P. simplex are meioeuryhaline oligohalobe species found in salinities of less than 3-5\% (Matthiessen \& Brenner, 1996).

It must be noticed that, despite the presence of this genus in sediments of different ages is considered one of the most reliable paleoecological markers of fresh water environments, Pediastrum can be recorded in significant numbers in some palynological studies of sediments deposited on or beyond the marine continental shelf. This marine sedimentary record may be occurs either as part of allochthonous associations that are washed by rivers and streams from the inland areas since it is easily transported palynomorph; or may be associated with periods of low relative sea level (Brenac \& Richards, 2001 and Tell \& Zamaloa, 2004). In addition, in the palynological record, as observed in the present case, different Pediastrum species

TABLE 2. Previous world-wide records of Scenedesmus species compiled from Palynodata Inc. \& White (2008); Nd= Not determined.

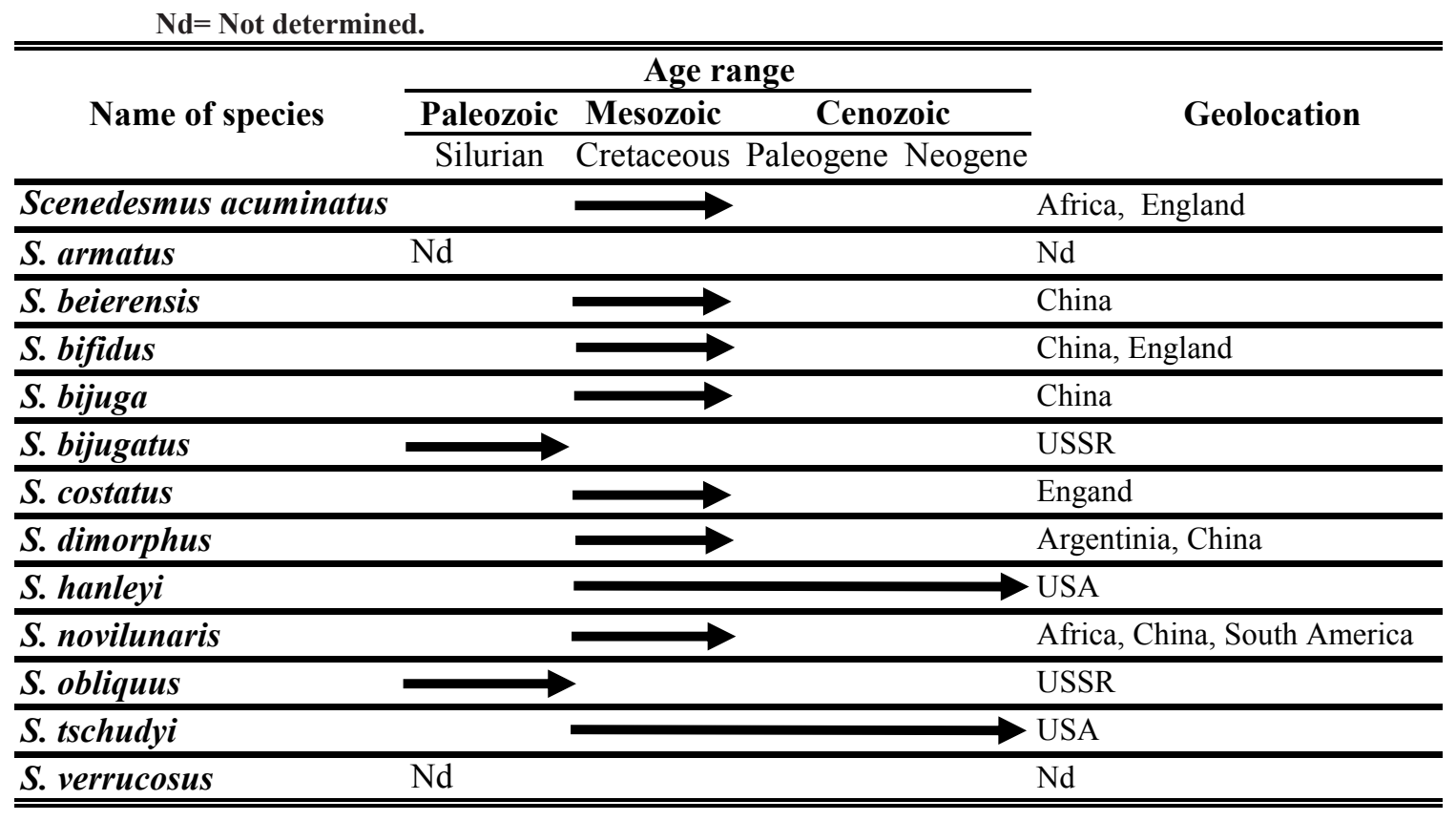

which may indicate a wide range of environmental response regarding turbidity, water chemistry, nutrient status and $\mathrm{pH}$ may be lumped together in the same sample. In such case, further knowledge on the ecology of the other palynomorph groups recorded in the same pollen slide is needed for accurate paleoecological interpretation.

Worldwide for both fossil and recent records, the most common and widely distributed species is $P$. boryannum which occurs in a variety of waters (Jankovská \& Komárek, 2000 and Komárek \& Jankovská, 2001). In contrast, there are several Pediastrum species that have the characters of relicts and occur in biotopes that are endangered in the present world. From them P. kawraiskyi which is recorded here for the first time from the Egyptian strata. The present distribution of this species is more restricted in comparison with fossil records and has a relict character (i.e., occurs only in clear, cold stenotherm water bodies, mainly in slightly eutrophicated lakes of colder areas of temperate zones) (Komárek \& Jankovská, 2001).

The stratigraphic record of the colonial fresh water alga Scenedesmus spans the Silurian to the present (about $443.7 \mathrm{Ma}$ ) (Table 2). According to data extracted from Palynodata Inc. \& White (2008), there are 13 species of Scenedesmus recorded worldwide from different geological strata (Table 2). S. acuminatus which is widely distributed in the recent microflora of Egypt, has been identified here for the first time from the Cretaceous strata of the country. 
The resistance of Scenedesmus to biodegradation is one of the puzzles of palynology. Earlier, Wille (1970) believed that the cell wall of Scenedesmus was composed of cellulose and pectin and would therefore not allow fossilization, but Pickett-Heaps (1975) demonstrated that the coenobia of Scenedesmus areacetolysis resistant and it is logic to occur as a fossil. This suggests the presence of a protective layer in its cell wall that presumably prevents chemical or bacterial degradation. Later studies about the cell walls of different algal taxa have reported that Scenedesmus is among the green algal genera that are capable of synthesizing sporopollenin in their cell walls (Burczyk \& Czygan, 1983; Komaristaya \& Grobulin, 2006 and He et al., 2016). Despite its persistance as palynomorph in the sediment, sometimes the identification of Scenedesmus to the species level shows more difficult, this may be due to the fact that the cell walls of the Scenedesmus coenobia are very thin so, some specimens appear to be crumpled and folded and sometimes the position of the cell contacts in the coenobia are obscured due to the poor preservation (Fleming, 1989).

Because modern Scenedesmus is restricted to fresh water habitats, fossil Scenedesmus is considered to be a reliable paleoenvironmental indicator for fresh water conditions (Fleming, 1989).

Chomotriletes is an extinct genus that was assigned to the extant family Zygnemataceae by Grenfell (1995). The form genus is fairly conservative in shape and ornamentation (a bilaterally-symmetrical cell with concentric to spiral striations on opposite faces), but it has several published synonyms such as Circulisporites, Concentricystes and Pseudoschizaea (Jansonius \& Hills, 1977 card no. 3322). It exhibits along fossil record from the Devonian to Cenozoic but it has never been collected alive. It seems to indicate the presence of wet and aquatic biotopes (Davis, 1992 and Leroy, 1992).

Regarding the very rare marine prasinophyte specimens encountered in the studied interval which represented by genus Pterospermella, it may be represent nearshore to onshore environments that had some marine influence, perhaps by tides or storms.

Finally, from the occurrence of the above mentioned fresh water chlorococcalean algal taxa we can conclude that the studied Cretaceous succession had been deposited near to an area of fresh water input. From this interpretation we can prove that, in paleopalynology algae which is one of non-pollen palynomorphs can be used as an important tool, besides pollen palynomorphs, to elucidate the paleoenvironmental conditions prevailed in the past ages.

Acknowledgment: Thanks and appreciation to the authorities of the Egyptian General Petroleum Corporation (EGPC) for providing the samples for this study. Thanks are also due to Prof. Jonna Lenarczyk (W. Szafer Institute of Botany PAS, Poland) for verifying of some species identification.

\section{$\underline{\text { References }}$}

Brenac, P. and Richards, K. (2001) Pediastrum as a guide fossil in sequence stratigraphy. In: Proceedings of the IX International Palynological Congress, Goodman, D.K., Clarke, R.T. (Ed.). American Association of Stratigraphic Palynologists Foundation, Houston, Texas, USA, pp. 239-241.

Brooks, J. and Shaw, G. (1972) Geochemistry of sporopollenin. Chem. Geol. 10, 69-87.

Brunner, U. and Honegger, R (1985) Chemical and ultrastructural studies on the distribution of sporopollenin like biopolymers in six genera of lichen phycobionts. Can. J. Bot. 63, 2221-2230.

Burczyk, J. and Czygan, F.C. (1983) Ocurrence of carotenoids and sporopollenin in the cell wall of Chlorella fusca and of its mutants. Z. FürPflanzenphysiol. 111, 169-174.

Davis, O.K. (1992) Rapid climatic change in coastal southern California inferred from Pollen Analysis of San Joaquin Marsh. Quaternary Research, 37, 89-100.

Eisenack, A. (1972) Kritische Bemerkungzur Gattung Pterospermopsis (Chlorophyta, Prasino phyceae). Critical remarks about Pterospermop sis. Neues Jahrbuchfür Geologie und Paläontologie, 10, 596601.

Evitt, W.R . (1969) Dinoflagellates and other organisms in palynological preparations. In: "Aspects of Palynology" Tschudy, R.H., Scott, R.A. (Ed.), pp. 439-481. Wileyinterscience.

Fleming, R.F. (1989) Fossil Scenedesmus (Chlorococcales) from the Raton Formation, Colorado and New Mexico, U.S.A. Rev. of Palaeobot. Palynol. 59, 1-6. 
Gawlik, S.R. and Millington, W.F. (1969) Pattern formation and the fine structure of the developing cell wall in colonies of Pediastrum boryanum. Amer. $J$. Bot. 56(9), 1084-1093.

Girard, V. (2009) Evidence of Scenedesmaceae (Chlorophyta) from 100 million-year-old amber. Geodiversitas, 31(1), 145-151.

Grenfell, H.R. (1995) Probable fossil Zygnematacean algae spore genera. Rev. Palaeobot. Palynol. 84, 201-220.

He, X., Dai, J. and Wu, Q. (2016) Identification of sporopollenin as the outer layer of cell wall in microalga Chlorella protothecoides. Front. Microbiol. 7, 1047. doi: 10.3389/fmicb . 2016.01047.

Hortobagyi, T. (1973) The microflora in the settling and subsoil water enriching basin of the Budapest Waterworks. Acad. Kiado. Budapest. 340 pp.

Ibrahim, M.I.A., Zobaa, M.K., El Noamani, Z.M. and Tahoun, S.S. (2017) A review of the angiosperm pollen genus Cretacaeiporites Herngreen, with one new species from the Upper Cretaceous of Egypt. Palynology, 41(1), 101-116.

Jankovská, V. and Komárek, J. (2000) Indicative value of Pediastrum and other coccal green algae in palaeoecology. Folia Geobot. 35, 59-82.

Jansonius, J. and Hills, L.V. (1977) "Genera File of Fossil Spores and Pollen". Special Publ., Geol. Dept., Calgary Univ., Canada.

Komárek, J. and Jankovská, V. (2001) Review of the Green Algal Genus Pediastrum; Implication for Pollen analytical research. Bibl. Phycol. 108, 1-127.

Komaristaya, V.P. and Gorbulin, O.S. (2006) Sporopollenin in the composition of cell walls of Dunaliella salina Teod. (Chlorophyta) zygotes. Int. J. Algae, 8, 43-52.

Leroy, S. (1992) Palynological evidence of Azollanilotica Dec in recent Holocene of the eastern Nile Delta and palaeoenvironment. Veget.Hist. Archaeobot. 1, 43-52.

Matthiessen, J. and Brenner, W. (1996) Chlorococcalalgen und Dinoflagellaten-Zystcn in rezenten Sedimenten des Greifswalder Bodden. Senckenbergiana Marit. 27(112), 33-48.

Mendonça, Filho, J.G., Menezes, T.R., Mendonça, J.O., Oliveira, A.D., Silva, T.F., Rondon, N.F. and Silva, F.S. (2012) OrganicFacies: Palynofacies and Organic Geochemistry Approaches. In:"Geochemistry-Earth's
System Processes" Panagiotaras, D. (Ed.). In Tech, pp. 211-248.

Palynodata Inc., White, J.M. (2008) Palynodata Datafile: 2006 version, with Introduction by White, J.M. Geological Survey of Canada Open File Report, No. 5793, 1 x CDROM and http://geopub.nrcan.gc.ca/ moreinfo_e.php?id=225704.

Pickett-Heaps, J.D. (1975) Green Algae: Structure, reproduction and evolution in selected genera. Sinauer Associates, Sunderland, Mass., 606 pp.

Pocock, S.A.J. (1970) Palynology of the Jurassic sediments of western Canada. Paleonotographica, 130, 12-72.

Prasertsin, T., Pekkoh, J., Pathom- aree, W. and Peerapornpisal, Y. (2014) Diversity, new and rare taxa of Pediastrum spp. in some freshwater resources in Thailand. Chiang Mai J. Sci. 41(5.1), 1065-1076.

Prescott, G.W. (1962) "Algae of the Western Great Lakes". Dubuque, Iowa, W. C. Brown Co. 977 pp.

Sarmaja-Korjonen, K., Sarmaja-Korjonen, A. and Bennike, O. (2006) Pediastrum algae from the classic late glacial BøllingSø site, Denmark: Response of aquatic biota to climate change. Rev. Palaeobot. Palynol. 138, 95-107.

Tell, G. (2004) Recent and fossil species of the genus Pediastrum Meyen (Chlorococcales) from Argentina and their geographical distribution. Algological Studies, 112, 49-71.

Tell, G. and Zamaloa, M. (2004) A Miocene algal assemblage dominated by Pediastrumleonensis $\mathrm{n}$. sp. (Chlorophyceae) from Patagonia, Argentina: Paleoenvironmental implications. Journal of Paleolimnology, 32, 247-254.

Traverse, A. (2007) "Palaeopalynology". $2^{\text {nd }}$ ed., Springer, $813 \mathrm{pp}$.

Tyson, R.V. (1993) Palynofacies analysis. In Jenkins DG (Ed.), Applied Micropalaeontology. Kluwer Academic Publishers, Netherlands, 153-191.

Wille, W. (1970) Plaesiodictyon mosellanumn. g., n. sp., eine mehrzellige Grünalgeausdem Unteren Keuper von Luxemburg. N. Jahrb. Geol. Paläontol. Mh. 5, 261-320.

(Received 15 / 10 /2017; accepted 23/11/2017) 


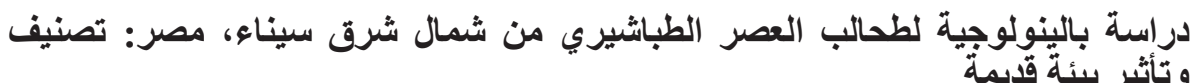

زينب محمد النعماني و أمل إبراهيم صالح

قسم النبات ـ كلية العلوم - جامعة عين شمس إير ــ القاهرة - مصر.

تعد مجموعة الطحالب الحفرية الدقيقة واحدة من أهم مجموعات NPPs الممثلة في الثر ائح البالينولوجية

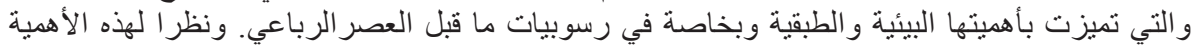

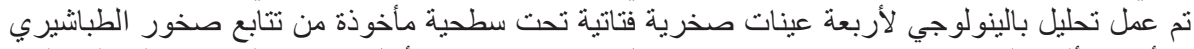

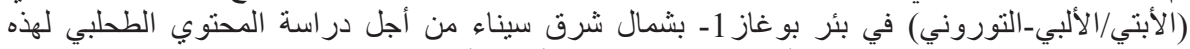

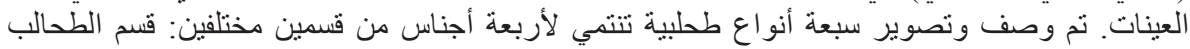

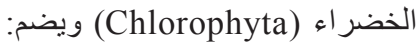

Pediastrum boryanum, P. duplex, P. kawraiskyi, P. simplex, Scenedesmus acuminatus و Chomotriletes minor وقسم البر اسينوفيتا Prasinophyta) ويضم .Pterspermella sp. وقد سجل النوعان Scenedesmus acuminatus و للمره الأولى من صخور العصر الطباشيري بمصر.

تم إعطاء نبذة عن المدي الزمني والتوزيع الجغر افي وكذلك طبيعة الجدار المقاوم للتحلل لأهم الأجناس

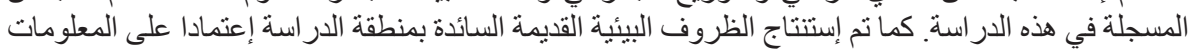

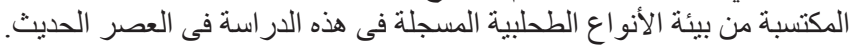

